\title{
Temporal trends in the referral pattern to and yield of cardiac MRI: an analysis from Saudia Arabia
}

\author{
Mouaz H Al-Mallah*, Ebtisam Anazi, Ahmed AlJizeeri, Mohsen AlHarthi, Ahmed AlSaileek \\ From 18th Annual SCMR Scientific Sessions \\ Nice, France. 4-7 February 2015
}

\section{Background}

Cardiac MRI was recently introduced in Saudia Arabia and is only available in few centers. The aim of this analysis is to describe the current referral pattern to cardiac MRI in Saudia Arabia.

\section{Methods}

This is a single center study that included patients who were referred for cardiac MRI for evaluation of clinical indications. The indications and baseline demographics of patients referred to cardiac MRI were collected. The different indications were compared in each year.

\section{Results}

A total of 1,581 patients ( $38 \%$ females) were included. In first few years of the initiation of the service, most patients were referred for assessment of viability (54\%) followed by assessment of etiology of cardiomyopathy (19\%). However, in the subsequent years, viability referrals decreased and there was a steady increase in other indications (assessment of LV function, arrhythmias, cardiac masses, congenital heart disease,..etc.) (figure). Referral to stress MRI continued to be very low (less than 1\%). $46 \%$ of the reoffered patients had an ejection fraction less than $50 \%$ and $42 \%$ of the patients had evidence of myocardial delayed enhancement.

\section{Conclusions}

In the first years of establishing a cardiac MRI program, assessment of viability and cardiomyopathy constitute more than two thirds of referral to cardiac MRI.

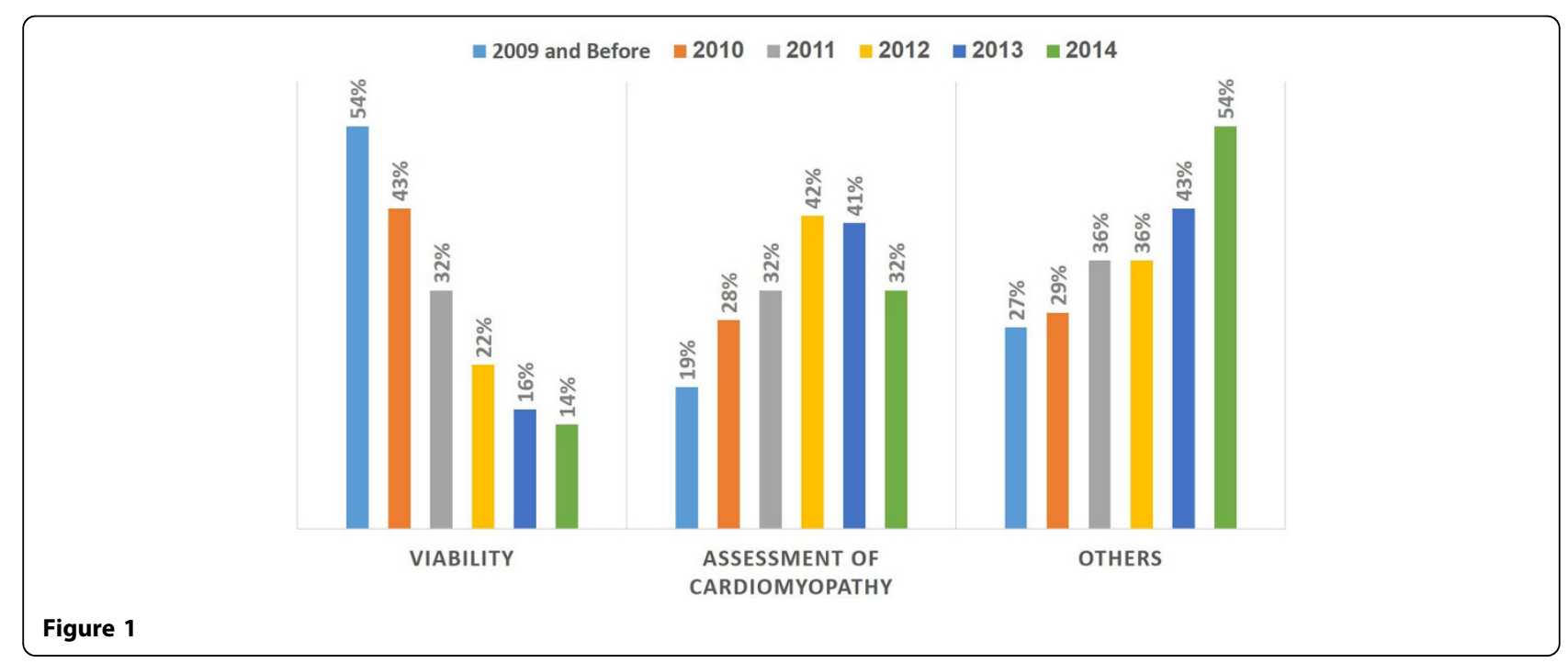

Cardiac Imaging, King AbdulAziz Cardiac Center, Riyadh, Saudi Arabia

(c) 2015 Al-Mallah et al; licensee BioMed Central Ltd. This is an Open Access article distributed under the terms of the Creative 


\section{Funding}

None.

Published: 3 February 2015

doi:10.1186/1532-429X-17-S1-P136

Cite this article as: Al-Mallah et al.: Temporal trends in the referral pattern

to and yield of cardiac MRI: an analysis from Saudia Arabia. Journal of

Cardiovascular Magnetic Resonance 2015 17(Suppl 1):P136.

Submit your next manuscript to BioMed Central and take full advantage of:

- Convenient online submission

- Thorough peer review

- No space constraints or color figure charges

- Immediate publication on acceptance

- Inclusion in PubMed, CAS, Scopus and Google Scholar

- Research which is freely available for redistribution

Submit your manuscript at 